\title{
THE DIAGNOSTICS OF PROFESSIONAL FOCUS AND VALUE- ORIENTED SPHERE OF PERSONALITY IN THE SYSTEM OF HIGHER EDUCATION
}

\author{
LILIA ROMANKOVA
}

\begin{abstract}
This article examines the importance of psychological and pedagogical research in the field of professional focus and value orientation sphere of personality in the higher education system, which can provide an opportunity to model the pedagogical activity in order to shape important professional qualities of future specialists.
\end{abstract}

Keywords: personality, professional focus, value orientation sphere, education system, professional higher education.

The enquiry into future specialist's professional focus is of great importance due to $21^{\text {st }}$ century higher education requirements. Higher education is undergoing radical changes. It is expected to train a new generation, ready for the challenges of post-industrial society. The guarantee of professional competence of a specialist is currently one of the issues investigated against the backdrop of increased scholarly attention to the professional formation of the new generation in the system of continuous education, in other words life-long learning.

Search for an optimal solution is based primarily on the idea of humanization, emphasis on the intrinsic value of a human being, discovering his or her capabilities, meeting their diverse needs, and promoting the free development. A true expert only then meets the social expectations if his or her personality, general and professional culture develops at a faster pace comparing to the younger generation. Formation of highly trained professionals, who are proactive, thinking, and self-critical, is only possible if teaching and education in higher educational establishments meet the real needs of modern society. A lot of theoretical and practical studies (A. A. Verbitsky, O. B. Kaganov, N. V. Kuzmina, V. A. Slastonin, N. M. Talyzina and others), have been devoted to developing different aspects of professional focus, but in order to meet new requirements for teaching young specialists we still urgently need to find new visions in order to solve the complex problems of their training. Pedagogical achievements in the field of professional focus are based on the principles established by psychology scholars such as L. Bozovic, A. Leontiev, V. Merlin, K. Platonov, S. Rubinstein. Despite their different approaches to the interpretation of the term "professional focus", the general conclusion is that it depends on the hierarchy of motivational sphere of personality. It should be noted that most of these sources although focused on the formation of motivational sphere of personality and the level of interest in the profession, underestimate important indicators of the process such as personal orientation of an individual towards revealing and comprehending the social and cognitive motivations 
(usefulness and importance of a future professional activity), and emotional development component, which are prerequisites for the formation of professional focus. Therefore, existing approaches to professional focus differ theoretically and by their terminological guidelines.

The analysis of academic sources makes it possible to assert that considering the focus as a complex structural formation of personality, researchers face many difficulties. First, there is a terminological difference. Views on the concept of "focus" reflect the ambiguity in the interpretation of the term: "dynamic tendency" (S. Rubinstein), "sensemaking motive" (A. Leontiev), "dominant attitude" (V. N. Myasischev) "basic life orientation" (B. G. Ananiev) "dynamic organization of a human`s "essence of strength"" (A. Pranhishvili). In the process of the analysis we concluded that focus is a collection of human dominant motives and needs that determine the main strategy of behavior, activities, communication, and selective attitude of a human to reality. As a complex personal formation, professional focus is manifested differently in various professions and fields of knowledge, depending on their specific characteristics. Thus one professional sector differs from another by its objective and substantive characteristics. Professional focus as a generalized form of an attitude to the profession consists of individual, local assessments of the degree of personal significance (attractiveness - unattractiveness) of various aspects of professional activity, its content, and the conditions of its performance. The topic of evaluation of subjective significance may include such aspects of professional activities as an opportunity to perform creative tasks, work with people, correspondence with professional abilities and personality, competitive salary and so on.

Professional focus is defined as a complex psychological phenomenon that characterizes the level of mental readiness for choosing a future career path (B. Fedoryshyn), determines the choice of a career path and the process of becoming a specialist (V. Bodrov), is generic form of a person's relationship to the profession (N. V. Kuzmin), is an integral feature of an individual that determines person's relation to the chosen profession (B. F. Lomov), represents the level of commitment to career choices (G.S. Kostyuk). In our work we approach the professional focus of future specialists as an integral systemic trait that provides the proper attitude to the profession, the inclination for professional work and commitment to it.

The formation of professional focus is distinguished by increasing complexity due to the hierarchical structure of the focus as well as to the influence of multiple objective and subjective factors on the process of formation. Motivation as a driving force of human behaviour, is of course central to the structure of an individual, which encompasses main components of individual such as education, focus, emotions, skills, activities and mental processes. Yet the problem of formation of professional focus should not be reduced only to the question of motivation to a certain professional activity. The complex dialectical relationship of the individual and the environment, its inherent mental premises and social phenomena that contribute to the formation of professional focus, indicate the need to consider each of the components that reflect the subjective and objective structure of the process. Changing even one of these factors causes a change in the process of formation of professional focus. Knowing the structure of professional focus and of its characteristics as well as considering the driving forces of the process is necessary in order to successfully guide this process.

Taking into account the existence of different approaches to structuring professional focus and the state of solving this problem in practice, we believe that value orientation sphere, which accumulates experience of the individual, and correlates with the level of maturity, plays an important role in the structure of professional focus. In the course of professional education students structural value semantic sphere is formed. It includes two main components - value orientation and the system of personal meanings. The value orientation of a future specialist, a construct which can be seen as a strategic objective of one's activities, plays crucial role in the regulatory system of motivational behavior and professional activities and influences the content and direction of their needs, motivation and interests.

Despite the complexity of the concepts of "value" and "value orientation", modern scholars are trying to rationally describe their semantic nature and development dynamics. In particular, S. Karpenko notes that "value is a necessary correlate of mental, therefore we can talk about axio- 
psychic, or a value semantic sphere of the individual that can be seen as a representative of externalinternal, subject-object appropriate connection of phenomena, affirming the teleological approach as the leading methodological principle of axiological psychology of personality" [1, p. 465]. Mastering one's motivational-semantic sphere means understanding it, which functions as a self-identifying mechanism. In studies of E. Klimov [2] and V. Shadrikov [3] value orientation is depicted as an important mechanism for regulating activity. The importance of this system is most obviously manifested in relation to the future professional activity. In this case crucial professional qualities are derivative from value hierarchy.

Development of values system of future specialists can be evaluated by an attitude to following main components of professional activities: awareness of the objectives of educational interaction, interest in the process of interaction with the students and its results; unconditional acceptance of student's personality, the desire to help in the process of spiritual and cultural development; positive self-concept as a set of ideas about own personal and professional qualities [4, p. 281].

Another component of value-semantic sphere of personality is a system of personal meanings. In the scientific psychological literature, the concept of personal meaning is interpreted as an awareness of significance of certain objects and phenomena of reality, which is defined by their role and place in human life and activity. Personal meanings are consciously acknowledged, important for the individual body of knowledge about people's behavior, social norms, roles, values and ideals. Thus, according to the statements of B. Bratus, meaning acts in the human consciousness as something that directly represents and encompasses vital relationships of a person [5, p. 301]. D. Leontiev's understanding of the concept of meaning is somewhat different. He considers meaning to be a component of the perceived images of corresponding objects and ideas that reflect their meaning for the subject and present this meaning to the subject by means of emotional response to images and their transformations [6, p. 181].

The value-semantic model of personality proposed by I. Yarmatkeiev was of particular significance for our study [7]. This model puts forward the value-mediated professional-semantic focus as a system building principle. According to this theory, in the process of the formation of future specialist's personality all the attention should be focused on the establishment and development of his or her semantic sphere as a centre for professional and personal self-regulation based on a free, value-oriented choice that provides true professional and personal self-realization and freedom for his or her professional and personal self-expression [7, p. 92].

Therefore, sense, as well as values, is one of the main components of value-semantic sphere of a human being. Meanings express a personal subjective attitude of a human being to the world. The achievement of meaning is connected to the reflection of the relationship of a person to the world, and it is shaped by an activity and particular human behavior. Understanding the value-semantic sphere of personality as a set of values, value orientations, meanings and other meaningful motivations of activity and behavior brings us to the recognition of the special importance of the process of its formation throughout training.

Given the importance of studying professional orientation and value-orientation spheres of the first year students, over the years 2012-2016 we have conducted an experimental study in Transcarpathian National University, which analysed the answers of 6029 respondents. In the first phase of the study we applied John Holland's theory of vocation choice based on personality types and G. Leevy`s approach to studying the value orientation spheres. The significance of John Holland's method is that it determines the degree of correlation of personality type with the preferred field of professional activities. In terms of the selection of specialized education and career, professional work success and satisfaction depend primarily on the way personality type matches the typical professional environment. Representatives of the particular profession are more or less homogeneous in their psychological characteristics because each profession attracts people who share common interests, attitudes, inclinations, physiological properties, etc. Since representatives of each professional group are characterized by certain similarity, they react in the same way to many situations, thus creating 
their own interpersonal environment. Thus, it is rightly to affirm the existence of a model of professional environment that surrounds a person.

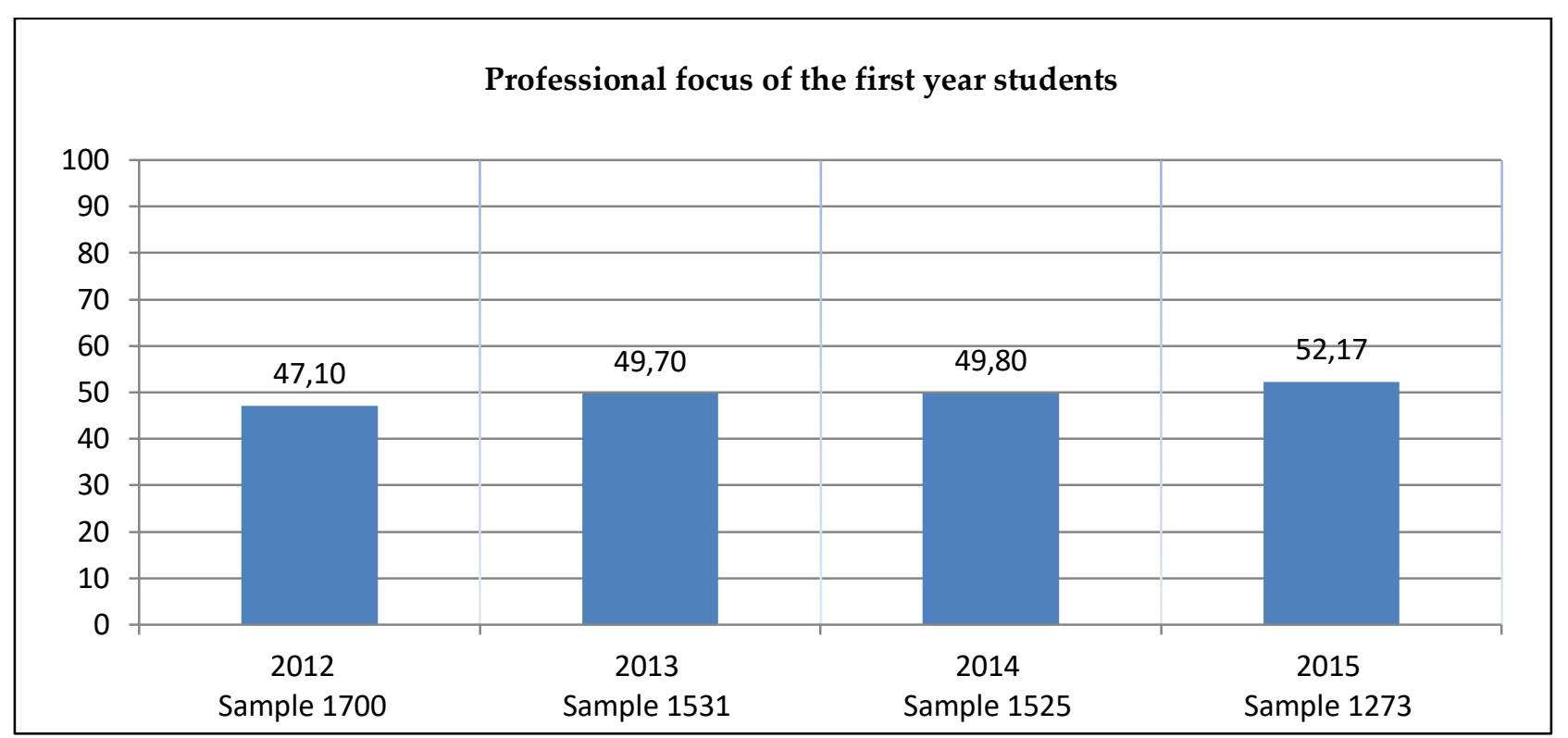

Fig. 1. Professional focus of the first-year students.

Fig. 1 illustrates the results of psychological and pedagogical research, according to which it can be argued that around $50 \%$ of applicants arriving to the university every year are professionally oriented. Such results make it possible to create conditions for further professional development of students and to identify the main objectives of the educational process: the forming of professional (targeted, semantic, operational) guidelines; forming a system of professionally important knowledge, shaping scientific and cultural worldview; forming professionally important skills; development of professionally important abilities (intellectual, perceptual, communicative, expressive, organizational, language and so on.); development of the spiritual needs of a future specialist, moral and ethical perfection of his or her personality; promoting self-actualization and self-development of each individual.

Values orientations method, developed by G. Leevyk, is of considerable interest due to the significant role values play both in personal and professional development of a young specialist.

The role of value orientations in students ' professional focus is that they determine professional behavior, providing content and direction of activities. The advantage of this method is that it reveals professional values and demonstrates how they can become a means of achieving the life goals.

\begin{tabular}{|c|c|c|c|c|}
\hline № & Value of life goals & Average rate & Means of achieving life goals & Average rate \\
\hline 1. & $\begin{array}{c}\text { VO towards material } \\
\text { goods }\end{array}$ & 5,11 & $\begin{array}{c}\text { VO towards development of } \\
\text { ethical qualities }\end{array}$ & 4,9 \\
\hline 2. & $\begin{array}{c}\text { VO towards } \\
\text { communication }\end{array}$ & 5,04 & $\begin{array}{c}\text { VO towards development of } \\
\text { moral qualities }\end{array}$ & 4,9 \\
\hline 3. & $\begin{array}{c}\text { VO towards social and } \\
\text { political activity }\end{array}$ & 4,9 & $\begin{array}{c}\text { VO towards development of } \\
\text { business qualities }\end{array}$ & 4,76 \\
\hline 4. & VO towards cognition & 3,36 & $\begin{array}{c}\text { VO towards development of } \\
\text { volitional qualities }\end{array}$ & 3,71 \\
\hline 5. & VO towards work & 2,52 & & \\
\hline
\end{tabular}

Tab. 1. Value-orientation (VO) sphere of first-year students (2012).

Number of students: 1707; Sample: 1700 respondents. 


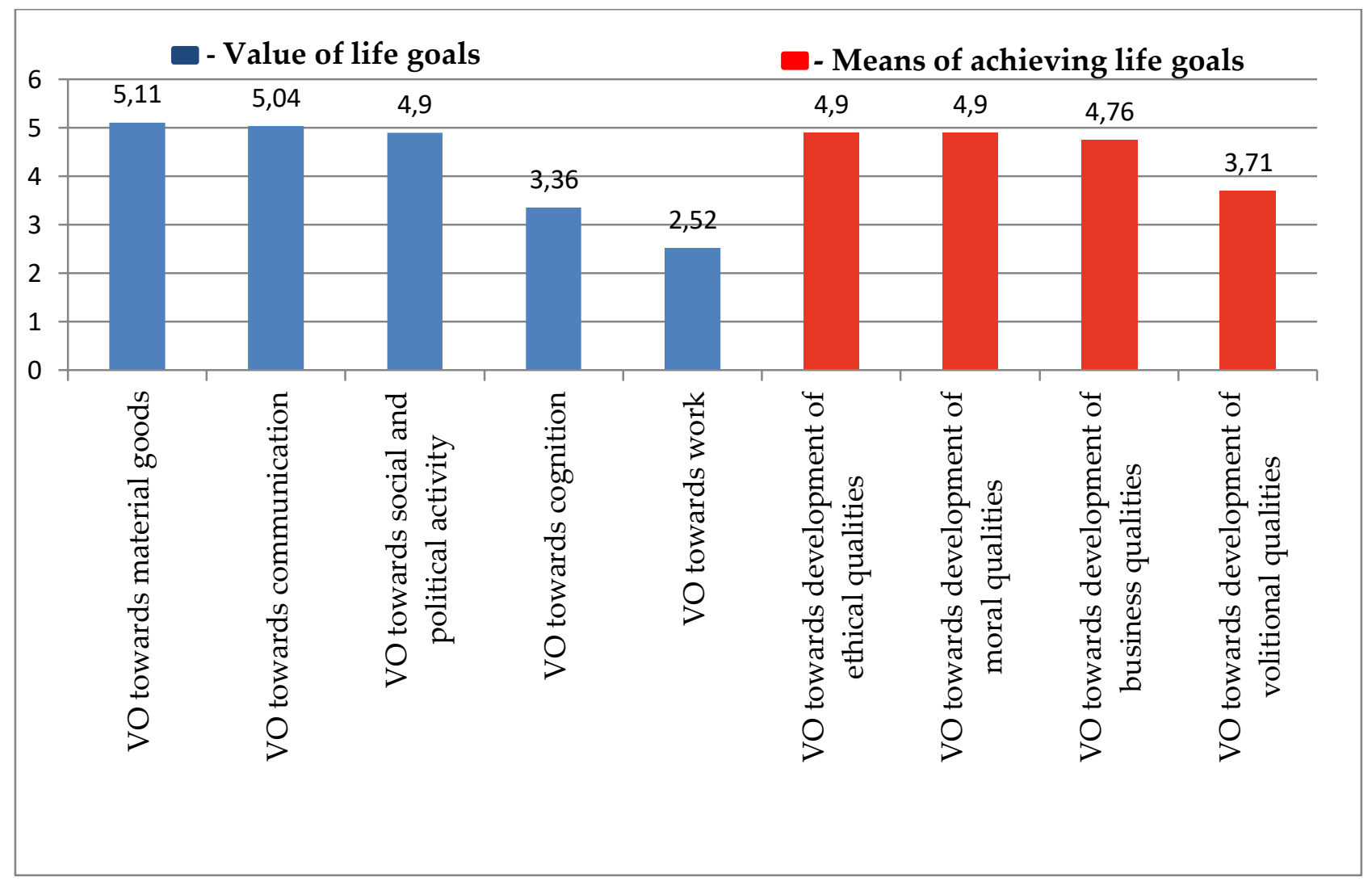

Fig. 2. Value-orientation (VO) sphere of first-year students (2012).

\begin{tabular}{|c|c|c|c|c|}
\hline № & Value of life goals & Average rate & Means of achieving life goals & Average rate \\
\hline 1. & VO towards work & 5,9 & $\begin{array}{l}\text { VO towards development of } \\
\text { volitional qualities }\end{array}$ & 5,9 \\
\hline 2. & $\begin{array}{l}\text { VO towards } \\
\text { communication }\end{array}$ & 5,7 & $\begin{array}{l}\text { VO towards development of } \\
\text { ethical qualities }\end{array}$ & 5,6 \\
\hline 3. & VO towards cognition & 5,7 & $\begin{array}{c}\text { VO towards development of } \\
\text { business qualities }\end{array}$ & 5,6 \\
\hline 4. & $\begin{array}{l}\text { VO towards material } \\
\text { goods }\end{array}$ & 5,3 & $\begin{array}{c}\text { VO towards development of } \\
\text { moral qualities }\end{array}$ & 5,2 \\
\hline 5. & $\begin{array}{l}\text { VO towards social and } \\
\text { political activity }\end{array}$ & 4,5 & & \\
\hline
\end{tabular}

Tab. 2. Value-orientation (VO) sphere of first-year students (2013).

Number of students: 1966; Sample: 1531 respondents. 


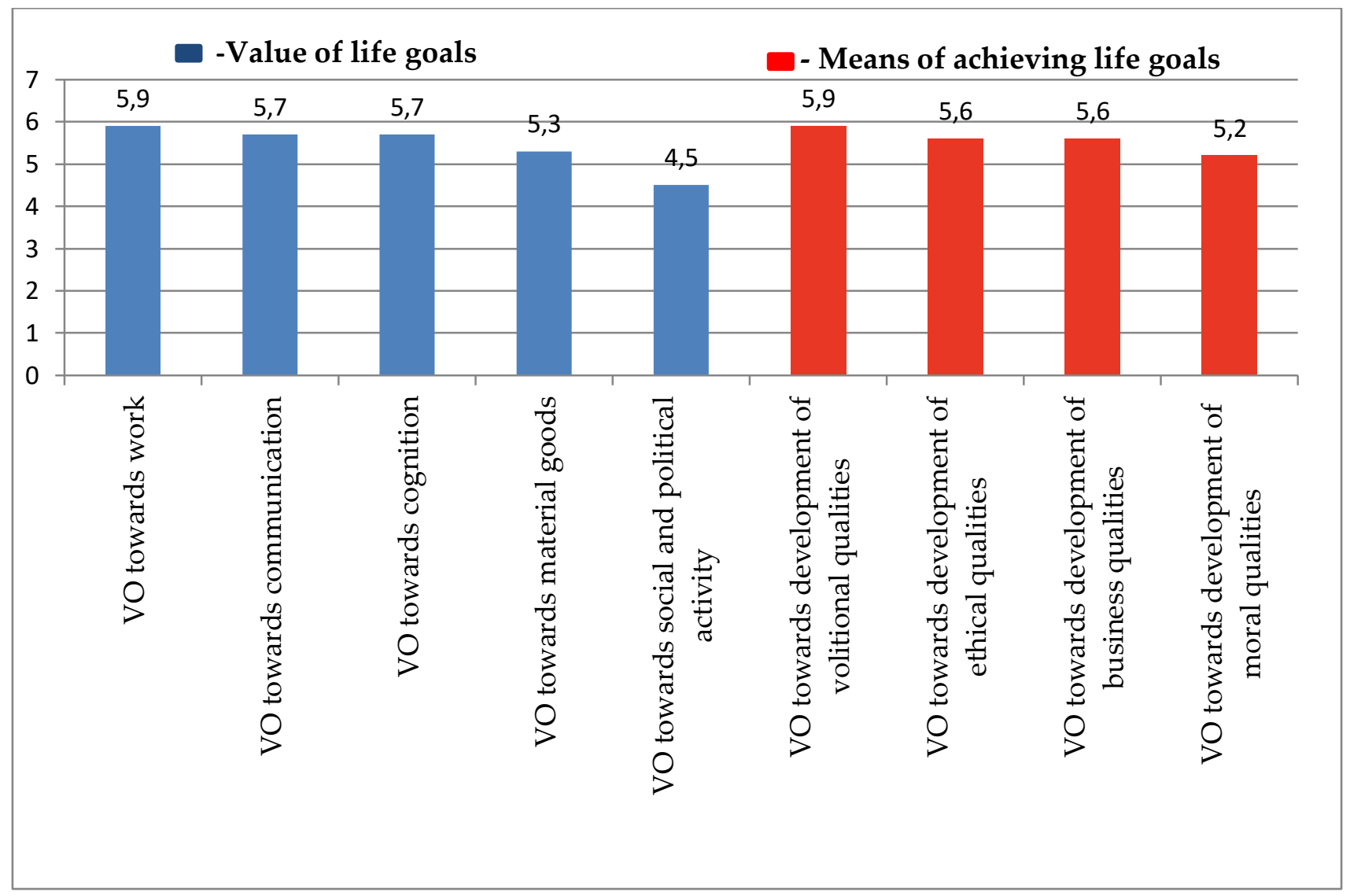

Fig. 3. Value-orientation (VO) sphere of first-year students (2013).

\begin{tabular}{|c|c|c|c|c|}
\hline № & Value of life goals & Average rate & Means of achieving life goals & Average rate \\
\hline 1 & $\begin{array}{c}\text { VO towards material } \\
\text { goods }\end{array}$ & 5.3 & $\begin{array}{c}\text { VO towards development of } \\
\text { volition qualities }\end{array}$ & 5.9 \\
\hline 2 & $\begin{array}{c}\text { VO towards } \\
\text { communication }\end{array}$ & 4.9 & $\begin{array}{c}\text { VO towards development of } \\
\text { ethical qualities }\end{array}$ & 5.6 \\
\hline 3 & VO towards cognition & 4.7 & $\begin{array}{c}\text { VO towards development of } \\
\text { business qualities }\end{array}$ & 5.6 \\
\hline 4 & VO towards work & 3.9 & $\begin{array}{c}\text { VO towards development of } \\
\text { moral qualities }\end{array}$ & 5.2 \\
\hline 5 & $\begin{array}{c}\text { VO towards social and } \\
\text { political activity }\end{array}$ & 3.5 & & \\
\hline
\end{tabular}

Tab. 3. Value-orientation (VO) sphere of first-year students (2014).

Number of students: 1962; Sample: 1525 respondents. 


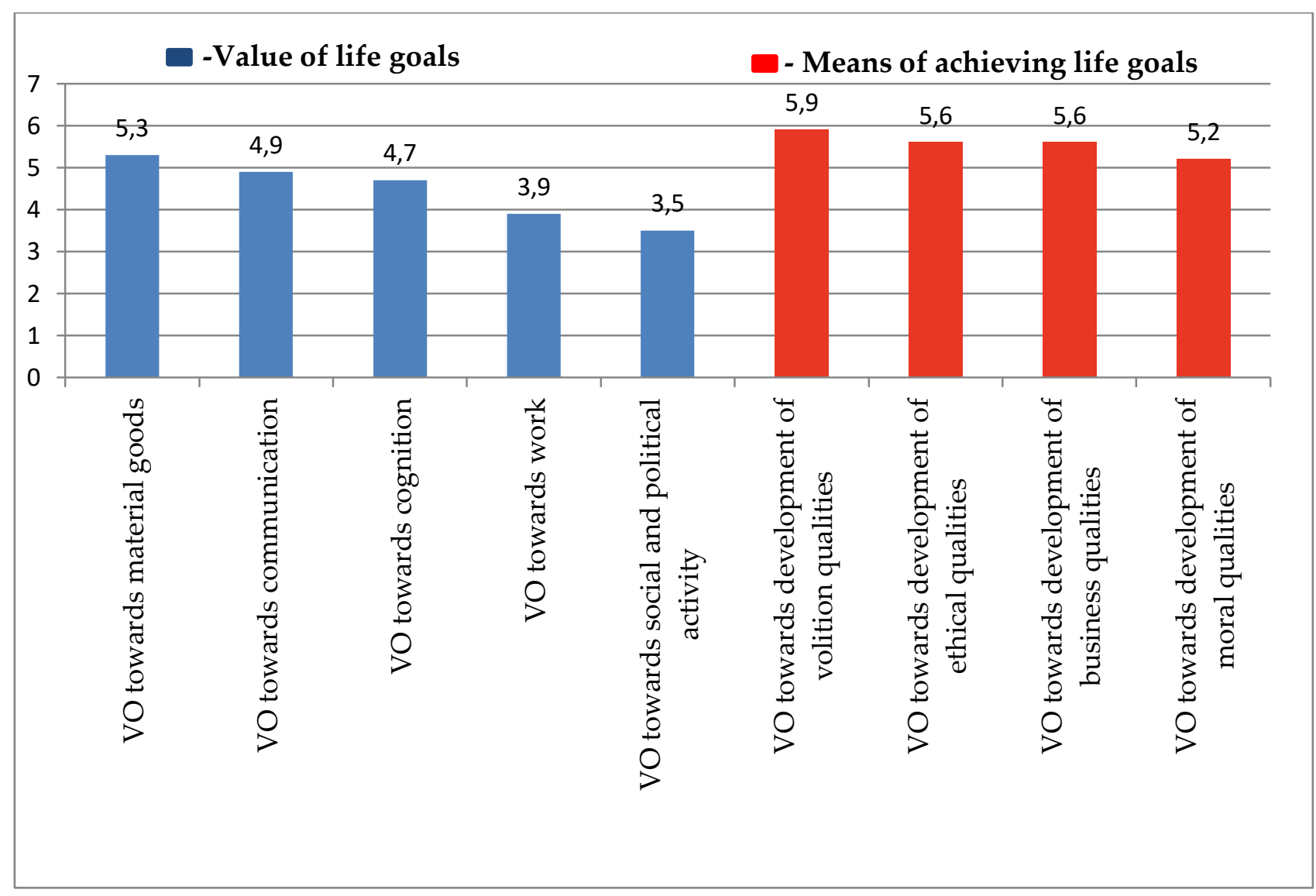

Fig.4. Value-orientation (VO) sphere of first-year students (2014).

\begin{tabular}{|c|c|c|c|c|}
\hline $\mathbf{N o}$ & Value of life goals & Average rate & Means of achieving life goals & Average rate \\
\hline 1 & VO towards work & 5,67 & $\begin{array}{c}\text { VO towards development of } \\
\text { volitional qualities }\end{array}$ & 5,8 \\
\hline 2 & VO towards cognition & 5,63 & $\begin{array}{c}\text { VO towards development of } \\
\text { ethical qualities }\end{array}$ & 5,52 \\
\hline 3 & $\begin{array}{c}\text { VO towards } \\
\text { communication }\end{array}$ & 5,56 & $\begin{array}{c}\text { VO towards development of } \\
\text { business qualities }\end{array}$ & 5,49 \\
\hline 4 & $\begin{array}{c}\text { VO towards material } \\
\text { goods }\end{array}$ & 5,23 & $\begin{array}{c}\text { VO towards development of } \\
\text { moral qualities }\end{array}$ & 5,23 \\
\hline 5 & $\begin{array}{c}\text { VO towards social and } \\
\text { political activity }\end{array}$ & 4,43 & & \\
\hline
\end{tabular}

Tab. 4. Value-orientation (VO) sphere of first-year students (2015).

Number of students: 1720; Sample: 1273 respondents. 


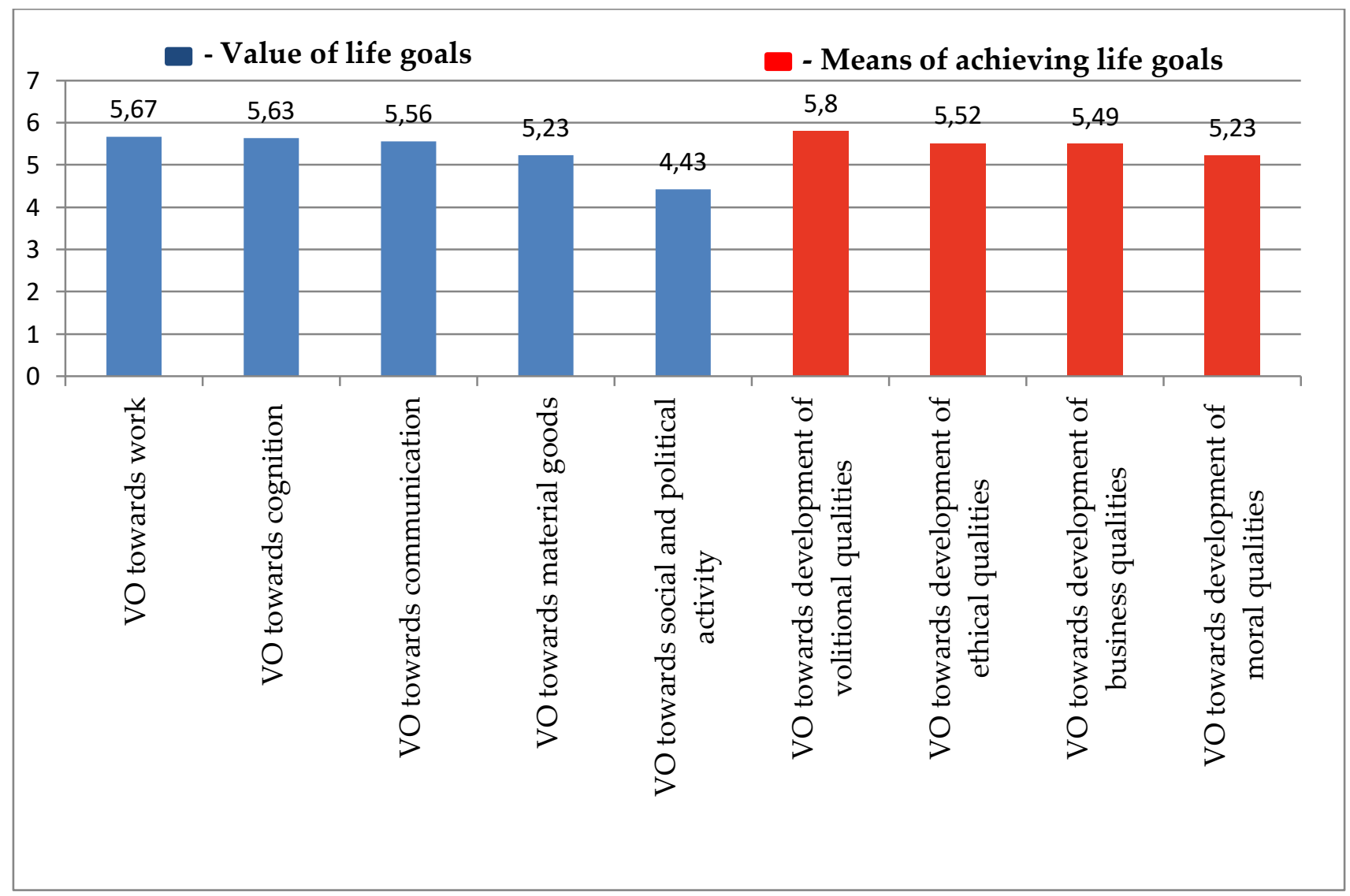

Fig. 5. Value-orientation (VO) sphere of first-year students (2015).

Figures from 1 to 5 illustrate the value-orientation sphere of first year students.

The first group of values, values of life goals, includes: value orientation towards work; value orientation towards communication; value orientation towards knowledge; value orientation towards social and political activities; value orientation towards material goods.

Analyzing the results of the research of value-orientation sphere of first-year students, we can state that in 2012 students were prioritizing: 1) orientation towards acquiring material goods, or group of values which comprise human need for material security; 2) orientation towards communication which are related to human needs of pleasure through interaction, including values such as awareness, presence of positive character traits that contribute to the communication process (cheerfulness, sense of humor), need to communicate during the holidays, discussing philosophy and everyday problems; 3) orientation towards social and political activity, which includes various types of community service such as promotion of knowledge and ideas, various sorts of community work in one 's own group and in the local community, as well as holding an elected office. 2013-2015 years students prioritize: 4) orientation towards work that summarizes values such as gaining professional experience, thorough knowledge of one's field of expertise, competency with modern technology in the industry, workplace satisfaction and awareness of significance of one's work, and finally 5) orientation towards cognition, which combines on the one hand human desire for self-improvement, broadening horizons, updating knowledge, growing culturally and intellectually, and on the other hand self-criticism, education, maturity and wisdom of life.

The group of values which are the means of achieving the goals of life includes orientation towards the development of ethical qualities; orientation towards the development of business skills; orientation towards the development of volitional qualities; orientation towards the development of moral character.

Value orientation towards the development of ethical qualities combines values that characterize the relationship of a man to other people: love to people, respect, compassion, sincerity, ability to forgive mistakes; value orientation towards the development of business skills that include a following 
set of values: organizational and pedagogical skills, initiative, independence and persistence, the ability to quickly and accurately assess the situation; value orientation towards the development of volitional qualities that is manifested in appreciation of persistence and motivation to overcome obstacles, commitment, endurance, courage, determination and self-confidence; the value orientation towards the development of moral qualities that characterize the relationship of a human being with him- or herself such as modesty, selflessness, high standards, sense of personal dignity as well as the ability to comprehend and to perceive the beauty in a human being, nature and art.

From what was stated above, one can conclude that the change in the value system of first-year students largely meets the following requirements set for the future specialist by knowledge society: gaining a rich professional experience, thorough knowledge of his or her field of knowledge and continuous self-improvement.

Thus, psychological and educational research makes it possible to model a pedagogue `s activity in order to subsequently shape professionally important qualities of future specialist based on the following factors:

- diagnostic factor, related to the study of psychological characteristics of the individual, the identification and evaluation of their general education and spirituality, as well as competencies necessary for their training, future professional and daily activities;

- orienting prognostic factor, which consists of the ability of the teacher to define specific goals, content or methods of educational activity, predict its results on the basis of knowledge about individual student's development and coherence and cohesion of the student community;

- constructive and projective factor that requires continuous improvement of teaching methods and implementing various educational activities. This activity requires a teacher to have a psycho-pedagogical approach to thinking, pedagogical focus as well as initiative, creativity, ability to operate a wide range of organizational and educational tools and deep knowledge of psychology and pedagogy;

- organizational, since the progress of the educational process and its measurable results depends on the skilful planning of educational work, determining optimal ways of its implementation, and the validity/justification of specific activities;

- practical solution (informational and explanatory) to specific educational problems which requires a teacher to have skills, abilities, knowledge of effective teaching methods in order to be able to implement what had been planned and in addition a perfect educational technique;

- communicative and motivating component, for the effective implementation of which teacher should be endowed with such personal qualities as humaneness (the quality of being a good person and the ability to accept students for who they are), empathy, ability to the keep the perspective, an optimistic approach to every student and creativity. These qualities are manifested through teacher's communication with students. The nature of this communication is expected to provide incentives for students to engage in socially valuable activity and behavior;

- analytical assessment, the purpose of which is to analyze one's own actions as well as those of the students, identify their positive and negative traits, compare the result with the plans; analytical assessment activity can provide the feedback that will help to timely identify specific results of educational work and make the necessary adjustments.

Taking into the account these psychological and educational factors allows the teacher to analyze the process of training and education, to adjust their actions and to improve their performance. This type of activity requires exceptional responsibility; its objectivity is the evidence of the maturity of the creative educator that has to cover all the activities and timely fill them with new meaning. This includes having skills and abilities that enable a creative approach to any activity. This also includes creative application of educational theory as well as research and development of new ideas, which go beyond the well-known theory and enrich it. 


\section{REFERENCES}

[1] Братусь Б.С. Аномалии личности. Наука, М., 1988.

[Bratus' B.S. Anomalyy lychnost. Nauka, M., 1988.]

[2] Карпенко 3.С. Аксіологічна психологія особистості. Ділея-НВ, Івано-Франківськ, 2009. [Karpenko Z.S. Aksiolohichna psykholohiya osobystosti. Lileya-NV, Ivano-Frankivs'k, 2009.]

[3] Климов Е.А. Общечедовеческие ценности глазами психолога-профессиоведа. Психологический журнал, 14 (4) (1993), 130-136.

[Klymov E.A. Obshchechelovecheskye tsennosty hlazamy psykholoha-professyoveda. Psykhol. Zhurnal, 14 (4) (1993), 130-136.]

[4] Пеонтьев Д.А. Психология смысла: природа, строение и динамика смысловой реальности, 3-е изд. Смысл, М., 2007.

[Leont'ev D.A. Psykholohyya smysla: pryroda, stroenye y dynamyka smyslovoy real'nosty. 3-e yzd. Smysl, M., 2007.]

[5] Сердюк О.О. Ціннісно-смисловий універсам людини (монографія). ТОВ “Юго-Восток, Атд”, Донецьк, 2007.

[Serdyuk O.O. Tsinnisno-smyslovyy universam lyudyny (monohrafiya). TOV “Yuho-Vostok, Ltd”, Donets'k, 2007.]

[6] Шадриков В.Д. Введение в психологию: мотивациия поведения. Аогос, Москва, 2003.

[Shadrykov V.D. Vvedenye v psykholohyiu: motyvatsyia povedenyia. Lohos, Moskva, 2003.]

[7] Ярмакеев И.Э. Моделирование личности современного учителя: цзенностно-смысловой аспект. Изд-во Казан. ун-та, Казань, 2004.

[Yarmakeev Y.E. Modelyrovanye lychnosty sovremennoho uchytelya: tsennostno-smyslovoy aspekt. Yzd-vo Kazan. un-ta, Kazan', 2004.]

Address: Lilia Romankova, Vasyl Stefanyk Precarpathian National University, 57, Shevchenko Str., IvanoFrankivsk, 76025, Ukraine.

E-mail: liliaromankova@gmail.com.

Received: 20.07.2017; revised: 22.09.2017.

Романкова Лілія. Діагностика професійної спрямованості та ціннісно-орієнтаційної сфери особистості в системі вищої професійної освіти. Журнал Прикарпатського університету імені Василя Стефаника, 4 (2) (2017), 115-124.

У статті розкрито значення психолого-педагогічні досліджень із питань професійної спрямованості та ціннісно-орієнтаційної сфери особистості в системі вищої професійної освіти, які дають можливість змоделювати діяльність педагога з метою формування професійно важливих якостей майбутнього фахівця.

Кдючові слова: особистість, професійна спрямованість, ціннісно-орієнтаційна сфера, система виховання, вища професійна освіта. 